\title{
QUALIDADE DA ÁGUA SUPERFICIAL DA SUB-BACIA HIDROGRÁFICA DO CÓRREGO HORIZONTE, ALEGRE/ES
}

\author{
Elton Almeida Bertossi ${ }^{1}$ \\ Ana Paula Almeida Bertossi ${ }^{2}$
}

Resumo: Com o objetivo de avaliar a qualidade da água superficial da Sub-bacia Hidrográfica do Córrego Horizonte, Alegre, ES, foram coletadas amostras de água para análise físico-química em diferentes locais da sub-bacia estudada, cada uma sob influência de diferentes usos do solo: pastagem, floresta e cafeicultura. As coletas foram realizadas duas vezes ao ano, uma no período de estiagem e outra no período de chuvas. De acordo com os resultados encontrados todas as amostras de água apresentaram-se em conformidade com a legislação, apenas para o fósforo total e ferro foram observados valores acima do máximo permitido. O que demostra que uma pastagem e cultivo agrícola (cafeicultura) quando bem manejados, adotando todos os princípios de conservação do solo, podem manter uma água de boa qualidade, como a encontrada em áreas florestadas.

Palavras-chave: Uso do solo; Rio; Parâmetros de qualidade.

\footnotetext{
${ }^{1}$ Ciências biológicas/Faculdade de Filosofia e Letras de Alegre, Brasil. E-mail: eltonbertossi@gmail.com.

2 Pós-doutorado em Produção Vegetal/Universidade Federal do Espírito Santo, Brasil. E-mail: anapaulabertossi@yahoo.com.br.
} 